\title{
PLANT-BASED MEDIATION CONTRIBUTION TO THE SETTLEMENT OF CASES AT THE COURT
}

\author{
Abdul Mustopa \\ Islamic Law Study Program Student, Concentration of Islamic Family Law \\ UIN Sunan Gunung Djati Bandung \\ Email: sportsextream2020@gmail.com
}

\begin{abstract}
Mediation is one of the stages in the trial process. Mediation must be carried out by the parties, who are disputing civil cases in all areas of the judiciary. Mediation is a law, as the State of Indonesia is a state based on law. Article 1 of the 1945 Constitution is a constitution that regulates the form of the state of Indonesia as a constitutional state. The contribution of offline and online-based mediation to the settlement of cases in the regional courts of the Mataram Religious High Court when combined, the two seem to be insignificant in resolving cases, both offline and online mediation. The low level of success is due to the mediator factor and the factor of justice seekers. The mediator factor is assessed due to the lack of ability (skills) of the mediator, the mediator only carries out mediation according to formal legal principles, the mediator does not master role knowledge, communication science, family psychology which results in rigidity in carrying out mediation, if the mediator has multiple disciplines, of course it will spawn. better results of the implementation of mediation. The justice seeker factor is judged due to the lack of seriousness in participating in a mediation forum led by a mediator and each of them has adhered to its principles.
\end{abstract}

Keywords: Mediation, Religious Court, Case, Islamic Law.

\section{A. INTRODUCTION}

Peace is a win-win case settlement system between the parties. No one feels defeated or defeated because in peace it prioritizes the principle of brotherhood in which egoism or coercion of the will will be more lenient so that both parties feel benefited. The feeling of defeating each other, winning and controlling the disputed goods does not arise or return to the product of peace based on the principle of brotherhood.

Mediation is one of the stages in the trial process. Mediation must be carried out by the parties, who are disputing civil cases in all areas of the judiciary. Mediation is a law, as the State of Indonesia is a state based on law (Dhomiri, 2017 : xi).

According to the mandate of the Republic of Indonesia Regulation No.1 of 2016 concerning Mediation Procedures in Courts, Article 13 explains the criteria for being a mediator. The criterion is a judge who is not a case examiner at the court concerned or another party who has a mediator certificate.

In March 2020. Indonesia and even the world experienced a deadly virus crisis called Covid-19. As a result of the Covid-19 pandemic outbreak, many laws have changed. New legal policies were born due to the corona outbreak, including in the mediation procession.

It is necessary to pay close attention to the role of a mediator in conducting the mediation process against the disputing parties. The roles are as follows: First, provide motivation to parties in trouble or dispute that even though it is being hit by an outbreak, it can still solve the 
problem. Second, being able to create creations, that the mediator must use various approaches and appropriate disciplines to support the process and achieve the goal, namely a peace agreement. Third, providing innovation, by ensuring that good intentions done in a good way and through the right media will get good results. Fourth, provide inspiration that mediation does not have to be done manually, but can be done electronically or online, using teleconference facilities and being able to take lessons from the existence of Covid-19 (KlikLegal.com, 2020).

Lessons from the Covid-19 pandemic have created a new culture marked by policies of all countries to raise awareness of the importance of health, safety and hygiene to break the chain of spread and transmission of Covid-19. The impact of Covid-19 all activities both government and economy and industry have decreased or even stopped temporarily. "So that information technology becomes one of the solutions and becomes the main means of carrying out activities or work. This change in concept resulted in all activities that are meetings, whether meetings, discussions, seminars, conferences, both national, regional and international using electronic or virtual means,

The Mataram Religious High Court was formed based on article 106 of Law Number 7 of 1989 jo. Decree of the Minister of Religion of the Republic of Indonesia Number: 95 of 1982. His domicile is in the capital city of NTB Province, namely Mataram City, with the address No. Majapahit Street. 58 Mataram, Tel. (0370) 621876 Fax. (0370) 642074. Mataram Religious High Court occupies a permanent building with II floors, built on land use rights of the Ministry of Religion located in Kekalik Village, Ampenan District, Mataram City.

The jurisdiction of the Mataram High Religious Court covers the provinces of Bali and NTB, consisting of 17 Religious Courts which are domiciled in the Capital City of the Regency / City Level II Region. Based on the Decree of the Chairman of the Supreme Court of the Republic of Indonesia regarding Class, Type and Area of Law, the First Level Courts and the Court of Appeal in the Four Courts of Appeal are divided into three class classifications, namely class IA for 2 Religious Courts, class IB for 5 Religious Courts, and class II for 10. Religious courts.

The religious court in the Mataram High Religious Court area, namely PA. Praya Class I B, PA. Badung Class II, PA. Praya Class I B, PA. Selong Class I B, PA. Sumbawa Besar Class I B, PA. Dompu Class I B, PA. Bima Class I B, PA. Giri Wins Class II, PA. Taliwang Class II, PA. Class II State, PA. Gianyar Class II, PA. Tabanan Class II, PA. Badung Class II, PA. Bangli Class II, PA. Singaraja Class II, PA. Klungkung Class II, PA. Karangasem Class II.

Of the number of Religious Courts in the Mataram High Religious Court area, not all of them were the objects of research in this dissertation. This dissertation research will examine 4 (four) courts, consisting of the Class II Badung Religious Court, the Class I B Praya Religious Court, the Class 1 B Dompu Religious Court and the Class II State Religious Court.

The Praya and Badung Religious Courts, which are Class $1 \mathrm{~B}$ and Class II courts located in Mataram City and Denpasar City, were selected as research objects on the grounds that the religious courts represent Class $1 \mathrm{~A}$ Religious Courts with a very large number of cases (many).

The Class 1 B Dompu Religious Court, located in Dompu Regency, West Nusa Tenggara Province, was chosen as the object of research on the grounds that the Religious Court 
represents the Class $1 \mathrm{~B}$ Religious Court with a relatively large number of cases, as well as various variations or types of cases, making it interesting for used as a place of research.

The Class II State Religious Court is located in Jembrana Regency, Bali. This Religious Court was chosen as the object of research on the grounds that the Religious Courts represent Class II Religious Courts with a very high success rate of mediation during 2019, so it is interesting to be the ideal location for research.

The dissertation research of 4 (four) courts, consisting of the Class IB Praya Religious Courts, Class II Badung Religious Courts, Class IB Dompu Religious Courts and Class II State Religious Courts, can represent the entire jurisdiction of the Mataram High Religious Court covering Nusa Province. West Southeast and Bali Province.

The area of the Mataram High Religious Court has now metamorphosed. By promoting mediation processions that are carried out online (virtual). So it is interesting to do studies and research.

The mediation cases that will be studied are cases in 2020, to be precise from March 2020 to December 2020. The reasons have been studied since March 2020, as the Covid-19 pandemic began. And starting to promote modern justice based on information technology, so as to allow for virtual mediation, so that it is in accordance with the problems to be examined in this dissertation.

The results of virtual mediation against cases of religious courts in the jurisdiction of the Mataram Religious High Court which is the objective of this dissertation research will be a benchmark, whether the implementation of virtual mediation in the Mataram Religious High Court area as regulated in Article 5 Paragraph 3 of the Regulation of the Supreme Court of the Republic of Indonesia Number 1 of 2016 concerning Mediation Procedures can produce a more successful peace, rather than face-to-face mediation in all types of civil cases in religious courts.

To answer the research questions as stated above, the researcher uses the following theories: First, for the grand theory, the theory of legal justice is used. (Butarbutar, 2009). Second, for the middle theory, the theory of legal certainty and usefulness is used (Sulardi, 2015). Third, for applicative theory, several theories are used, namely the theory of terms and the theory of law enforcement (Al-Jauziyah, 2006).

\section{B. METHOD}

The use of research methods is intended to obtain a number of information about the object that is the focus of the research so that it is in accordance with the research objectives. The object studied is the normative, juridical, sociological, philosophical, psychological and communicative theological approach and its implementation in the application of offline and online-based mediation to case resolution in the regional courts of the Mataram Religious High Court. (Nasution, 2008).

\section{RESULT AND DISCUSSION}

The function of mediation as a way of peaceful dispute resolution is motivated by many factors such as reducing the accumulation of cases in court, the tendency of humans to resolve problems in a peaceful way (win-win solution), accelerating the dispute resolution process and 
so on. So that by means of mediation, the interests and desires of the parties can be compromised with agreements that can benefit both parties (Sari, 2017).

Basically, mediation can be carried out outside the trial process in court. However, in divorce matters it is not possible to use a comprehensive system of out-of-court dispute resolution. However, like it or not, we have to follow the stages of the case process in court proceedings because the process of implementing a divorce itself must be carried out in court and not elsewhere.

In divorce disputes, the obligation to reconcile the parties is imperative and the Panel of Judges must give the parties the opportunity to make peaceful efforts outside the trial. The form of peace in disputes concerning material law (zaken recht) will automatically terminate the dispute and the peace agreed upon by both parties can be confirmed by a peace deed which has executive power.

In contrast to cases involving a person's status (personal recht) such as in divorce cases, if there is peace there is no need to make a peace deed which is strengthened by a peace decision. This is because it is impossible to make an agreement / provision that prohibits a person from doing certain actions such as prohibiting one of the parties from leaving the joint residence, ordering him to continue to love and cherish, to remain loyal, prohibit him from berating and so on because of these things if promised in a peace deed and then violated by one of the parties, then the peace deed cannot be executed. In addition, the consequences of that act and not doing it will not result in the termination of the marriage unless one of the parties filed a new lawsuit for his divorce. This is also to avoid accepting cases (Niet Onvankelijk Verklaat) based on the principle of nebis in idem.

Based on the considerations as mentioned above, the agreement to be reached is an agreement for harmony and peace, not an agreement to conduct a peaceful divorce. For this reason, in realizing the desire for peace in divorce cases, is to withdraw the case. This is in accordance with the provisions of Article 82 Paragraph 4 of Law Number 7 of 1989 concerning the Religious Courts.

Regarding material disputes or non-divorce disputes, cases that are successfully mediated will be manifested in the form of a peace deed which will be confirmed by a court ruling which ruled "punishing both parties obeying the contents of the peace deed". However, in the matter of divorce, successful mediation (harmonious and discontinuing the divorce) is not made a peace deed but only withdraws the lawsuit / petition.

After the case is withdrawn, the panel of judges in the area of the Mataram Religious High Court is to make a decision / decision and it is not enough that it is recorded in the trial minutes and removed from the case register. The need for a decision / decision product to be made is in line with the jurisprudence of the Supreme Court of the Republic of Indonesia, that divorce lawsuit must be rejected if peace has occurred between husband and wife and if it is rejected, a legal product must be made in the form of a decision or stipulation in accordance with applicable legal provisions (PERMA No 1 Tahun 2016 Tentang Mediasi, 2016).

Departing from this system, the researchers considered that the measure of the success of mediation in formal divorce cases is the number of divorce cases that were revoked. Although this does not rule out the possibility that the revocation process is not caused by the mediation process provided in the court, but sometimes through the consideration of the parties in the 
case itself. Because in principle the mediation process can be carried out as long as the case process in court is still ongoing, whether it is carried out through a mediation institution provided in court or outside the court which is carried out by the parties to the case themselves. Based on the results of research on mediation in the Mataram Religious High Court area, in this case the Class IA Badung Religious Court, the Class IA Praya Religious Court, the Class IB Dompu Religious Court and the Class II State Religious Court from September 2016 to August 2017, it can be found the research results are as follows:

\section{Badung Religious Court}

The Class 1 A Badung Religious Court is located in Badung City, which is a Class $1 \mathrm{~A}$ Religious Court with a very large number of cases (many) for the size of the Mataram PTA area, especially divorce cases, both divorce and divorce. In addition, the Badung Religious Court is geographically located in the heart of Bali Island. Ethnically, the people in Badung City are heterogeneous, there are Javanese, Balinese, Sundanese, Bugis, Makassar, Bima, Mataram and Oseng ethnic groups.

The Badung Religious Court is located in the capital city of Badung with an address at Jalan Cokroaminoto Gg. Catalia I Ubung Badung. The Badung Religious Court has 1 (one) building with the status of the State (Supreme Court of the Republic of Indonesia).

The Class $1 \mathrm{~A}$ Badung Religious Court in carrying out its duties and functions is to support the achievement of the vision and mission of the Supreme Court of the Republic of Indonesia as an implementing agency for judicial power in Indonesia with a vision of "The realization of the Great Badung Religious Court". The mission is "Providing independent judicial services, Maintaining the trust of justice seekers with a sense of justice oriented, Increasing the credibility and transparency of decisions and Producing superior Human Resources (HR)" (Visi Dan Misi, n.d.-a).

On the basis of this vision and mission, the Class $1 \mathrm{~A}$ Badung Religious Court of course fully supports the policy of the Supreme Court of the Republic of Indonesia regarding the implementation of Perma No.1 of 2016 concerning the Procedure for Implementing Mediation at the first level in resolving civil disputes, especially in divorce cases. As part of the objectives and strategy of the Class $1 \mathrm{~A}$ Badung Religious Court, namely to fulfill a sense of justice for justice seekers, in managing the litigation process for justice seekers according to the principles of fast, simple \& low cost and increasing public trust in religious courts.

One of the important points of evaluating the performance of the Class $1 \mathrm{~A}$ Badung Religious Court in resolving case disputes is to measure how many cases registered at the secretariat can be resolved through the mediation stage. The performance indicators are the comparison between mediation and the number of cases received, the comparison between cases that deserve to be mediated and those that are mediated, as well as the comparison between the mediation that is in process and the number of cases that have been successfully reconciled through mediation.

The circumstances of cases, both the remainder of the last year, and cases received and decided in 2020 at the Badung Religious Court are as follows:

Table I

Number of cases received in 2020 


\begin{tabular}{|c|c|r|}
\hline $\begin{array}{c}\text { The rest of the cases in } \\
2019\end{array}$ & Acceptance of cases in 2020 & Amount \\
\hline 93 Cases & 566 Cases & 659 Cases \\
\hline
\end{tabular}

Table II

Case decided in 2020

\begin{tabular}{|l|l|c|}
\hline \multicolumn{1}{|c|}{ No. } & \multicolumn{1}{|c|}{ Type of Verdict } & Number of Cases \\
\hline 1. & Granted & 561 Cases \\
\hline 2. & Aborted & 6 cases \\
\hline 3. & Rejected & 11 Cases \\
\hline 4. & Not accepted & 9 cases \\
\hline 5. & Crossed out & 4 cases \\
\hline 6. & Revoked & 56 Cases \\
\hline Total cases decided & 647 Cases \\
\hline \multicolumn{2}{|l|}{ Remaining cases in 2020 } \\
\hline
\end{tabular}

Table III

The cases filed for appeal in 2020

\begin{tabular}{|c|c|c|}
\hline No. & Description & Number of Cases \\
\hline 1 & The rest of 2019 & 1 \\
\hline 2 & Received in 2020 & 5 \\
\hline \multicolumn{2}{|r|}{ Number } & 6 \\
\hline 3 & Appeals cases decided in 2020 & 5 \\
\hline 4 & $\begin{array}{l}\text { The remainder of the appeal cases that have not yet } \\
\text { been decided }\end{array}$ & 1 \\
\hline
\end{tabular}

Tabel IV

Perkara-perkara yang dimohonkan Kasasi tahun 2020

\begin{tabular}{|c|l|c|}
\hline No. & \multicolumn{1}{|c|}{ Description } & Number of Cases \\
\hline 1 & The rest of 2019 & 2 \\
\hline 2 & Received in $2020 \quad$ Jumlah & 5 \\
\hline \multicolumn{1}{|c|}{} & 3 \\
\hline 3 & Cassation case decided in 2020 & 4 \\
\hline 4 & $\begin{array}{l}\text { The remaining cassation cases that have not yet been } \\
\text { decided }\end{array}$ & \\
\hline
\end{tabular}


Table $\mathrm{V}$

Cases filed for Reconsideration in 2020Cases filed for Reconsideration in 2020

\begin{tabular}{|c|l|c|}
\hline No. & \multicolumn{1}{|c|}{ Description } & Number of Cases \\
\hline 1 & The rest of 2019 & - \\
\hline 2 & Received in 2020 Jumlah & - \\
\hline \multicolumn{2}{|c|}{} & - \\
\hline 3 & PK cases decided in 2020 & - \\
\hline 4 & The rest of the PK cases that have not yet been decided & \\
\hline
\end{tabular}

The remaining cases that have not been decided in 2019 are 93 cases and 566 cases submitted in 2020, so that the remaining cases in 2019 will be added to the cases entering 2020 to 659 cases. In 2020647 had been decided and 12 cases were left.

a. Number of Cases Decided on Time

There were 646 cases decided on time (0-5 months), while those who dropped out over 5 months amounted to 1 case..

b. Number of Cases That Did Not File Legal Remedies for Appeal, Cassation and PK

Of the cases that entered in 2020 plus the remaining cases in 2019, 5 (five) cases filed legal remedies for appeal, 5 (five) cassation cases, and no PK legal remedies, 637 cases that have been decided have not made legal remedies.

c. Number of Civil Cases Successfully Mediated

Of the cases that were submitted in 2020 , there were 129 cases that were mediated successfully, 1 case, and 128 cases that were not successfully mediated..

Table VI

Settlement of mediation cases

\begin{tabular}{|c|c|c|c|c|}
\hline Work unit & $\begin{array}{l}\text { amount } \\
\text { Case }\end{array}$ & succeed & Not successful & The rest \\
\hline $\begin{array}{c}\text { PA } \\
\text { Badung. }\end{array}$ & 129 & 1 & 128 & - \\
\hline
\end{tabular}

Based on the table of research results in the Class $1 \mathrm{~A}$ Badung Religious Court, that the ratio between the case load that is registered (registered) and the cases that deserve to be mediated is relatively small, namely on average or around $19.5 \%$ (nineteen point five percent) cases that can be mediated of the cases registered. The case load for PA Badung throughout 2020 was 659 (six hundred and fifty nine), while 129 (one hundred and twenty nine) cases were eligible for mediation.

Meanwhile, the percentage of success of cases that deserved mediation was $0.7 \%$ (zero percent) on average. There were 129 mediations in PA Badung throughout 2020, but only 1 case was successfully reconciled. Meanwhile 128 other cases were unsuccessful to be reconciled, so they had to continue at the main examination stage of the case. 


\section{Praya Religious Court}

The Praya Religious Court Class $1 \mathrm{~B}$ is located in Mataram City, Lombok Island, West Nusa Tenggara. The Praya Religious Court Class $1 \mathrm{~B}$ annually receives relatively large cases, especially divorce cases, both divorce and divorce. The Polewali Court jurisdictionally covers 6 (six) districts.

The Praya Religious Court is geographically located in West Nusa Tenggara Province. The majority of people in the city of Mataram are Lombok and Javanese and Bima.

The vision of the Praya Religious Court is "The realization of the Great Praya Religious Court", with a mission (Visi Dan Misi, n.d.-b):

a. Realizing a simple, fast, low cost and transparent trial.

b. Improve the quality of the resources of the judicial apparatus that are accountable.

c. Increase internal guidance and supervision.

d. Improve the quality of administrative management

e. Improve services to people who seek justice.

To realize this vision and mission, of course the Praya Class $1 \mathrm{~B}$ Religious Court has various kinds of indicators, for example indicators of success in mediation by reconciling a married couple through a mediator and being able to reconcile married couples who have been on the verge of divorce, as well as reconcile the disputing parties..

Table I

Remaining Cases in 2019 and Cases Received and Decided

Year 2020 by the Praya Religious Court

\begin{tabular}{|c|c|c|c|c|c|c|c|}
\hline $\begin{array}{c}\text { REMAIN } \\
\text { END } \\
2019\end{array}$ & $\begin{array}{c}\text { ENTERING } \\
\text { CASES IN } \\
2020\end{array}$ & AMOUNT & $\begin{array}{c}\text { TERM OF } \\
\text { DISCUSSION }\end{array}$ & REVOCED & $\begin{array}{c}\text { THE CASE } \\
\text { WAS } \\
\text { SCRATCHED } \\
\text { AND } \\
\text { DISMISSED } \\
\text { AND } \\
\text { REJECTED }\end{array}$ & REST & PERCENTAGE \\
\hline 190 & 2.612 & 2.802 & 2.637 & 130 & 13 & 165 & $100 \%$ \\
\hline
\end{tabular}

Table II

Cases Received by the Praya Religious Court by Type in 2020 plus the remainder of 2019 in 2020

(Based on Case Type)

\begin{tabular}{|c|l|c|c|c|}
\hline NO & \multicolumn{1}{|c|}{ TYPES OF CASES } & 2019 & 2020 & AMOUNT \\
\hline 1. & Polygamy Permit & - & 3 & 3 \\
\hline 2. & Divorce Divorce & 32 & 275 & 307 \\
\hline 3. & Divorce Lawsuit & 129 & 1.008 & 1137 \\
\hline
\end{tabular}




\begin{tabular}{|c|l|c|c|c|}
\hline 4. & lommon Property & 4 & 13 & 17 \\
\hline 5. & Child Mastery / Hadhonah & - & 4 & 4 \\
\hline 6. & Trusteeship & 1 & 6 & 7 \\
\hline 7. & Isbat Nikah & - & 1058 & 1.058 \\
\hline 8. & Dispensation of Marriage & - & 156 & 156 \\
\hline 9. & Determination of the Heir / P3HP & - & 11 & 11 \\
\hline 10. & Inheritance & 22 & 61 & 83 \\
\hline 11. & Cancellation of Marriage & - & 1 & 1 \\
\hline 12. & Negligence of Husband and Wife Obligations & - & 1 & 1 \\
\hline 13. & The Origin of Children & - & 3 & 3 \\
\hline 14. & Guardian Adol & - & 4 & 4 \\
\hline 15. & Grant & - & 3 & 3 \\
\hline 11. & Etc & 2 & 5 & 7 \\
\hline & AMOUNT & 190 & 2.612 & 2.802 \\
\hline
\end{tabular}

Table III

Cases Decided by the State Praya Court in 2020

(Based on Case Type)

\begin{tabular}{|c|l|c|}
\hline NO & \multicolumn{1}{|c|}{ Type of Cases } & Amount \\
\hline 1. & Polygamy Permit & 3 \\
\hline 2. & Divorce Divorce & 281 \\
\hline 3. & Divorce Lawsuit & 1.036 \\
\hline 4. & Common Property & 15 \\
\hline 5. & Child Mastery / Hadhonah & 4 \\
\hline 6. & Trusteeship & 7 \\
\hline 7. & Isbat Nikah & 1.062 \\
\hline 8. & Dispensation of Marriage & 149 \\
\hline 9. & Determination of the Heir / P3HP & 9 \\
\hline 10. & Inheritance & 55 \\
\hline 11. & The Origin of Children & 3 \\
\hline 12. & Guardian Adol & 4 \\
\hline 13. & Grant & 3 \\
\hline 14. & Etc & 6 \\
\hline & amount & 2.637 \\
\hline
\end{tabular}

Number of cases decided on time

Cases decided on time ( $<5$ months) $2020=2,532$ cases

Cases decided not on time ( $>5$ months) $2020=105$ cases

Table IV

Number of Cases to Appeal at the Praya Religious Court 2020

\begin{tabular}{|c|l|c|}
\hline No & \multicolumn{1}{|c|}{ Description } & Number of Cases \\
\hline 1. & Rest of 2019 & - \\
\hline 2. & Accept 2020 Amount & 15 \\
\hline \multicolumn{2}{|c|}{ A } & 15 \\
\hline 3. & Break up in 2020 & 9 \\
\hline
\end{tabular}




\begin{tabular}{|c|l|c|}
\hline 4. & The rest & 5 \\
& With details : & 5 \\
a. Not yet sent to PTA & \\
b. Has been sent to PTA & - \\
c. Revoked & 3 \\
\hline
\end{tabular}

Table V

Number of Cases Cassation at the Praya Religious Court 2020

\begin{tabular}{|c|l|c|}
\hline No. & \multicolumn{1}{|c|}{ Uraian } & Jumlah Perkara \\
\hline 1 & Rest of 2019 & 1 \\
\hline 2 & Accept 2020 Amount & 7 \\
\hline \multicolumn{1}{|c|}{$|c|$} \\
\hline 3 & Break up in 2020 & 1 \\
\hline 4 & The rest & 7 \\
& With details : & 1 \\
& a. Not yet sent to PTA & 6 \\
& b. Has been sent to PTA & - \\
& C. Revoked & \\
\hline
\end{tabular}

Table VI

Number of Cases for Review (PK) at the Praya Religious Court 2020

\begin{tabular}{|c|c|c|}
\hline No. & Uraian & Jumlah Perkara \\
\hline 1 & Rest of 2019 & 1 \\
\hline 2 & Accept 2020 & 1 \\
\hline \multicolumn{3}{|c|}{ Amount } \\
\hline 3 & Break up in 2020 & 1 \\
\hline 4 & $\begin{array}{l}\text { The rest } \\
\text { With details : } \\
\text { a. Not yet sent to PTA } \\
\text { b. Has been sent to PTA } \\
\text { c. Revoked }\end{array}$ & $\begin{array}{l}1 \\
- \\
1 \\
-\end{array}$ \\
\hline
\end{tabular}

Table VII

Number of Cases That Did Not Make Legal Remedies for Appeal, Cassation, and Pk at the Praya Religious Court 2020

\begin{tabular}{|c|c|c|c|c|c|c|}
\hline $\begin{array}{c}\text { The } \\
\text { rest of } \\
\text { the } \\
\text { end of } \\
2019\end{array}$ & $\begin{array}{c}2020 \\
\text { entry } \\
\text { cases }\end{array}$ & Amount & $\begin{array}{c}\text { Case } \\
\text { broke }\end{array}$ & Revoked & $\begin{array}{c}\text { Who did not make } \\
\text { an appeal for } \\
\text { cassation, pk }\end{array}$ & $\begin{array}{c}\text { Who made the } \\
\text { appeal for } \\
\text { cassation, pk }\end{array}$ \\
\hline 190 & 2.612 & 2.802 & 3 & 130 & 7.886 & 25 \\
\hline
\end{tabular}


\begin{tabular}{|l|l|l|l|l|l|}
\hline & & & & & \\
\hline
\end{tabular}

Based on the table of research results indicators in the Praya Class $1 \mathrm{~B}$ Religious Court, the comparison between cases that are submitted and cases that deserve to be mediated is relatively small, on average around $15 \%$ (fifteen percent) of cases that can be mediated from the number of cases registered, for example in October 2016 the number of cases entered the PR was 46 (forty six) cases, out of the 46 (forty six) cases it turned out that only 9 (nine) cases were subject to mediation process, while the rest were unable.

The mediation success rate of cases that deserve to be mediated on average is $0 \%$ (zero percent), for example in November 2016 out of 5 (five) cases that were mediated, only 1 (one) case was successfully reconciled by withdrawing the case, if analyzed carefully. Overall, during November 2016 to August 2017, out of 78 (seventy eight) cases that were eligible for mediation, only 4 (four) cases were successfully reconciled by withdrawing their cases.

\section{Dompu Religious Court}

The Class I B Dompu Religious Court is located in Dompu City, although the Class II Dompu Religious Court has a large number of cases. Located in Dompu Regency, it is one of the regencies in the province of West Nusa Tenggara with a location between 1170 - 1180 East Longitude and 80 - 90 South Latitude with the following boundaries:

North side: Flores Ocean and Bima Regency

South side: Indonesian Ocean

West side: Sumbawa Regency

East side: Bima Regency

Dompu District includes 8 (eight) sub-districts including: Hu'u District, Pajo District, Dompu District, Woja District, Kilo District, Kempo District, Manggalewa District, Pekat District, with 81 Villages / wards consisting of 9 Kelurahan and 72 Village. With an area of 2,324.55 KM2 with a city height ranging from 15-62 $\mathrm{m}$ above sea level, this area includes Satonda Island covering an area of 472 hectares.

The location of Dompu Regency, which is between Sumbawa and Bima Regencies, is mostly hilly, the rest is agricultural land, which has been used as regional facilities and infrastructure including office buildings, roads and other facilities.

Public transportation that can be used for community mobility are bemo / minibus, benhur (horse-drawn carriage or cidomo) and motorcycle taxis. Meanwhile, buses are used for intercity transportation between districts within the province and even outside the West Nusa Tenggara region.

To get to Dompu Regency, it can be reached by land or air. If you use the bus from Mataram, it can be taken for 10-11 hours, including crossing the Alas Strait by ship for about 2 hours. If you use an airplane, the route Badung - Bima takes about 1 hour plus 2 hours of road trip from Bima to Dompu, while the plane with the Mataram - Bima route takes 1 hour 15 minutes plus 2 hours of road trip from Bima to Dompu. (Wilayah Yurisdiksi, n.d.). 
The vision of the Class I B Dompu Religious Court is "The realization of a Great Religious Court", to implement this vision, the Class I B Dompu Religious Court has a mission (Visi Dan Misi, n.d.-c) :

a. Increase the independence and professionalism of the Dompu Religious Court apparatus.

b. Realizing prime and just legal services.

c. Realizing the modern management of the Dompu Religious Court.

d. Increase the credibility, transparency and accountability of the Dompu Religious Court..

In order to realize this vision and mission, of course the Class IB Dompu Religious Court certainly has requirements that must be fulfilled, such as a mission regarding awareness and legal compliance of the community in Dompu City, this legal awareness can be described as in divorce cases, divorce cases as far as possible are resolved in a peaceful manner, The settlement of divorce cases is not only through a divorce decision, but can also be done by reuniting broken household ties. The most essential thing to reduce the divorce rate is by means of mediation, even for other non-divorce cases. It is hoped that mediation can reduce the divorce rate and can improve the quality and expectations of family unity, as well as reconcile other non-divorce cases..

\section{CONLUSION}

The contribution of offline and online-based mediation to the settlement of cases in the regional courts of the Mataram Religious High Court, when combined, do not appear to be very significant in resolving cases, both conventional and virtual mediation. Except in Class II State Religious Courts, whose mediation success rate reaches $67 \%$, so that they are able to resolve cases non-litigation against cases received.

Based on research data from March to December 2020, it can be concluded that even though mediation efforts have been made maximally by the mediating judge, it turns out that the results of this mediation cannot reduce the number of divorces, with an average success rate of below $1 \%$ (one percent), far from the expectation of the issuance of Supreme Court Regulation No.1 of 2016 concerning Mediation Procedures in Courts, the low level of success is due to the mediator factor and the justice seeker factor. The mediator factor is assessed due to the lack of ability (skills) of the mediator, the mediator only carries out mediation according to formal legal principles, the mediator does not master role knowledge, communication science, family psychology which results in rigidity in carrying out mediation, if the mediator has multiple disciplines, of course it will spawn. better results of the implementation of mediation. The justice seeker factor is judged because of the lack of seriousness in participating in a mediation forum led by a mediator and each of them has adhered to its principles.

\section{References}

Al-Jauziyah, I. Q. (2006). Al-Turuq al-Hukmiyyah fi al-Siyasah al- Syar'iyyah-Hukum Acara peradilan Islam (A. Qihar, Trans.). Pustaka Pelajar.

Butarbutar, E. N. (2009). Konsep Keadilan Dalam Hukum Perdata. Mimbar Hukum, 12.

Dhomiri. (2017). Gugatan Perbuatan Melawan Hukum Syariah (PMHS) Dalam Hukum Islam. Puslitbang Diklat Kumdil. 
KlikLegal.com. (2020, June 15). Mediasi Elektronik di Era New Normal di Tengah Pandemi. KlikLegal. https://kliklegal.com/mediasi-elektronik-di-era-new-normal-di-tengahpandemi/

Nasution, B. J. (2008). Metode Penelitian IImu Hukum. Mandar Maju.

PERMA No 1 Tahun 2016 Tentang Mediasi. (2016). https://www.pnsubang.go.id/index.php?id=1327

Sari, S. W. (2017). MEDIASI DALAM PERATURAN MAHKAMAH AGUNG NOMOR 1 TAHUN 2016. Ahkam, 5(1).

Sulardi. (2015). Kepastian Hukum, Kemanfaatan, Dan Keadilan Terhadap Perkara Anak Kajian Putusan Nomormor. 201/Pid.Sus/2014/PN BIt. Jurnal Yudisial, 8(3).

Visi dan Misi. (n.d.-a). Retrieved April 25, 2021, from https://pa-badung.go.id/tentangpengadian/visi-dan-misi

Visi dan Misi. (n.d.-b). Retrieved April 25, 2021, from https://pa-praya.go.id/tentangpengadian/visi-dan-misi

Visi dan Misi. (n.d.-c). Retrieved April 25, 2021, from https://www.pa-dompu.go.id/tentangpengadian/profile-pengadilan/visi-dan-misi

Wilayah Yurisdiksi. (n.d.). Retrieved April 25, 2021, from https://www.pa-dompu.go.id/tentangpengadian/profile-pengadilan/wilayah-yurisdiksi 